\title{
MI FÁN TEREM AZ AKCIONISTA TUDOMÁNY? MÓDSZERESEN BESZÁMOLÓ
}

\author{
https://doi.org/10.51624/SzocSzemle.2019.1.6
}

Szakmai közéleti diskurzusra reflektáló rovatunkban folytatjuk a Módszeresen előadás-sorozatról szóló beszámolók közlését.

A Módszeresen címú szociológiai metodológiai előadás- és vitasorozat 2016 őszén indult. A szervezők (Janky Béla, BME-MTA; Gárdos Judit, MTA; Németh Renáta, ELTE TáTK; Szakadát István, BME) tervei szerint az előadások és viták olyan módszertani kérdésekre koncentrálnak, amelyek alapvető fontosságúak, és amelyekkel kapcsolatban új eredmények születtek a közelmúltban és/vagy élénk viták zajlanak a nemzetközi tudományos közösségben. A szervezők fel szeretnék hívni a gyakorló kutatók figyelmét azokra a területekre, ahol megfontolandó bizonyos korábbi kanonizált gyakorlatok felülvizsgálata - de nem szeretnék, hogy a sorozat a régiek helyett új kánonokat jelöljön ki. Ahogy beharangozójukban írják: „Célunk, hogy a hallgatók kanonizált szokások követése helyett képesek legyenek az adatok, eszközök és következtetések kritikai megközelítésére, módszereik megújítására saját korlátaiknak és az általuk képviselt tudomány határainak szem előtt tartásával. Azt gondoljuk, hogy a módszerekről való párbeszéd a szociológia mint diszciplína intellektuális jövője szempontjából lényeges."

\section{Mi fán terem az akcionista tudomány?}

Vajda Róza (MTA TK SZI) ${ }^{1}$

A Módszeresen vitasorozat hatodik eseményén a tudomány és a tudományosság határait feszegető akciókutatások kerültek terítékre. ${ }^{2} \mathrm{Az}$ antropológiai résztvevő megfigyelésen alapuló, illetve a szociológiai terepmunka mellett ez a harmadik irányzat olyan közösségben zajló és egyszersmind közösségépítő jelleggel bíró kutatási forma, amelynek - nem csak eredményein, hanem már a folyamatán keresztül is - közvetlen szándéka a társadalom jobbítása. Vajon alkalmasabb-e erre az akciókutatás a hagyományos módszertanokhoz képest? És nem válik-e a tudományosság kárára, ha kép-

\footnotetext{
1 A cikk megírásának hátterét a 115644 sz. OTKA-projekt biztosította.

2 Az akciókutatásoknak pár éve külön számot szentelt az AnBlokk (2011/5), a Kovász 2018. tél-tavaszi száma pedig beszélgetést közölt öt magyarországi kutatóval a részvételi akciókutatásokról.
} 
zetlen kutatókra van bízva a tudás előállítása? Ezeket a fő kérdéseket járta körül a beszélgetés és az azt követő vita.

A beszélgetőpartnerek, Kovai Cecília (MTA KRTK) és Udvarhelyi Éva Tessza (AVM, Közélet Iskolája), mindketten kulturális antropológusok, akik saját kutatói és aktivista tapasztalataik alapján vitattak meg a tudományos kutatások felépítésével, módszereivel, céljaival, illetve tudomány és aktivizmus viszonyával kapcsolatos kérdéseket. ${ }^{3}$ A beszélgetést Katona Noémi (MTA TK SZI) vezette. ${ }^{4}$

A beszélgetőtársak érdeklődéséből, társadalmi érzékenységéből, munkájából adódóan, de a résztvevő akciókutatás (RAK) segítő, öntudatosító jellegénél fogva is a beszélgetés súlypontja a hátrányos helyzetű, marginalizált csoportokra helyeződött. Az ő esetükben nyilvánvalóan kiváltképp kiélezettek a tudományos megfigyelés tárgyiasító sajátosságával, kutató és kutatott viszonyával, a tudás hozzáférhetőségével és a tudomány hasznával kapcsolatos dilemmák. Hangot adni olyan tapasztalatoknak, amelyekről nincsen szó a közbeszédben és a tudományos diskurzusban, vagy éppen károsan félreértelmezik azokat: ez volna az érintettek bevonásával megvalósuló kutatások egyik fő célja, miközben - ahogy Kovai hangsúlyozta - ezt diktálja a klasszikus társadalomtudományos hivatás is. Az alábbiakban a hagyományos kutatási helyzetekhez, módszertanokhoz képest mutatkozó azonosságok és különbségek, előnyök és hátrányok szempontjából foglalom össze, milyen érvek, értékelések merültek fel a vita során a RAK-ra vonatkozóan.

\section{Öszinte részvétel}

A RAK fő sajátosságát és egyszersmind létjogosultságát az adja, hogy a kutatásban feltárni szándékozott problémák által érintettek bevonásával, közösségben valósul meg. Ideáltipikus esetben, ha kívülálló személy kezdeményezi is a kutatást és a módszereket is ő javasolja, a téma menet közben alakul, és a csoport együtt bonyolítja le a projektet, aminek során minden döntést közösen hoznak. Igazi demokráciagyakorlatról van tehát szó, ami már a teljes értékű, azaz őszinte részvételnek köszönhetően is megerősíti a társadalomból amúgy kirekesztett csoportok tagjait; ezt tetézi, hogy a saját ügyükben járnak el. Udvarhelyi szerint a RAK természetes közege a mozgalom, ahonnan organikusan nő ki és ahová visszaforgatja az eredményeit. Számára ebből az is következik, hogy a részvételi szándék nem jelent külön problémát, és sem a projekt létrejöttét, sem a lebonyolítását nem befolyásolják külső megkötések, elvárások. Mint

3 Kovai elsősorban kutató, doktori disszertációját a cigány-magyar együttélésről írta Gömbalja faluban végzett terepmunkája alapján. Miután gyakorlati tevékenységnek is szükségét érezte, közösségfejlesztőként dolgozott hátrányos helyzetû fiatalokkal, így lett post-doc kutatásának témája a roma közösségek fejlesztése. Udvarhelyi az AVM (A Város Mindenkié) és a Közélet Iskolájának alapítójaként aktivistának definiálja magát. Azelőtt rangos hazai és külföldi egyetemeken tanult, az elmúlt években pedig számos kutatást szervezett és vezetett hajléktalan, lakhatási szegénységben élő és mozgássérült emberek részvételével.

4 Katona úgyszintén kettős szerepben találta magát, miután egy szociális ellátószervezet munkatársaként Németországban terepmunkába kezdett a prostitúcióról. Ezzel kapcsolatos élményeiről a Szociológiai Szemle 2017/2. számában számolt be. 
hangsúlyozta: „Én még soha nem csináltam pályázati kényszerből semmit”; amit tettek, azért tették, mert úgy érezték, szükség van rá.

Ezt az önmagába zárt világot kontextualizálta Kovai, megkérdőjelezve az azt strukturáló viszonyrendszer egalitarizmusát. A RAK közege, logikája, eredménye valóban sajátosan közösségi jellegú, ami megkülönböztetett diskurzusszabályaiban is testet ölt - hangsúlyozta -, de attól még ugyanúgy része egyenlőtlenségek szabdalta világunknak, mint bármely más kutatási helyzet: „Egyikünk se tudja magát kilőni a társadalmi struktúrából és azon kívül tevékenykedni." Kovai a RAK egyik nehézségét abban látja, hogy sokszereplős, komplex folyamat lévén többféle tudást és különféle érdekeket mozgósít, ezek kezelése, összehangolása pedig magas erőforrásigényú: a résztvevőket össze kell toborozni, meg kell szervezni, ki kell fizetni. Marginalizált csoportok esetében eleve kérdés, ki engedheti meg magának egyáltalán, és milyen feltételekkel, hogy beszálljon egy ilyen projektbe. Udvarhelyiék például ösztöndíjat, utazási támogatást biztosítottak a résztvevőknek, és gondoskodtak róla, hogy legyen mindig étel a találkozókon. Állítja ugyanakkor, hogy bár számított a munkájuk anyagi kompenzálása, alapvetően mindenki az önfejlesztés igényével vágott neki a feladatnak. Kovai szerint már a fejlesztés szándéka, diskurzusa is - akárcsak a tudományos kutatásé - középosztálybeli értelmiségi habitusból fakad; az így meghatározott projektekbe vonják be aztán az érintetteket azok, akik ezt megtehetik. Kutatásban és aktivizmusban egyaránt megúszhatatlan az egyenlőtlen viszony; ha valaki ilyen illúzióval indul el, az „inkább az egyenlőtlenség elfedésének eredménye, mintsem a meghaladása".

Érdekes kísérlet a helyzeti egyenlőtlenségek kiküszöbölésére az, amikor a projektet kezdeményező képzett kutató elfojt bizonyos tudásokat, elfelejt alapvető tudománytechnikai fogalmakat és igyekszik nem szánni több időt, energiát a felkészülésre és a közös munkára, mint a társai. Ilyen demokratikus önkorlátozást gyakorolt Udvarhelyi, amikor ráhangolódott a RAK sajátos, lassabb ritmusára: ezáltal hagyott érvényesülni másokat és segítette elő, hogy közös gondolkodás terméke lehessen a kutatás. Kovai számára a klasszikus kulturális antropológia is magában rejt egyfajta demokratizáló potenciált, mégpedig a résztvevő megfigyelés személyességének köszönhetően. Ő maga erre hagyatkozva engedi alakulni a viszonyait a terepen: tisztázva ugyan, mit keres ott, de szabadon hagyva, miként tekintsenek rá. Szerinte a nyitottságon múlik az is, felfüggesztődnek-e a kutató eredeti „tudományos” kérdései, hogy új témák, összefüggések kerülhessenek be a kutatásba. Mindezzel együtt Kovai távolságtartó, ragaszkodik a kutatás és az írás terepeinek klasszikus elkülönítéséhez, mivel ha a más közegnek szánt eredményeket visszaviszik a kutatás helyszínére, az „több bajt okozhat, mint amennyi haszon származik belőle”.

\section{Akciók és változások}


Éppen ez a különbségtétel nem létezik az akcionizmus számára, hiszen kutató és kutatott ugyanaz a személy, megszűnik „a laboratóriumi nézegetés”, ahogyan Udvarhelyi fogalmazott. Ô maga az öntudatra ébredésben látja a RAK lényegét, emiatt szeretett bele annak idején és lett „naiv, szőke pasaréti lányból politikai aktivista”. Azóta is azt tekinti feladatának, hogy másoknak is alkalmat teremtsen ennek az élménynek az átélésére. Másfelől a tartós társadalmi változások elérésében látja a RAK célját - és éppen ezért nem tartja szerencsésnek az egyszeri eseményt sugalló „akció” megnevezést. Kérdés persze, a résztvevők számára feltárulnak-e a RAK jóvoltából olyan perspektívák, hogy mondjuk naiv, szőke pasaréti lány váljék belőlük.

Udvarhelyi a RAK-ot emancipatorikus hatású közösségi munkának tartja, ami pedig a tudományos eljárásokat illeti, nem tér le a kitaposott ösvényről, mondván: „Nekem fontosabb a politikai meg az aktivista kimenet, mint az, hogy maga a módszertan milyen." A RAK innovatív potenciálja számára a következményeiben, felhasználhatóságában, azaz a tudományon kívüli szférában keresendő, ahol egyébként komoly sikereket könyvelhet el: közösségben végzett kutatásaik nyomán a rendőrség kénytelen volt változtatni a hajléktalanokkal szembeni bánásmódján, mozgássérült érdekvédelmi csoport jött létre, és általában fokozódott az állampolgári tudatosság és cselekvőkészség. Ezzel együtt felmerül, hogy az inkább befelé ható önkutatás mint az érdekképviselet előszobája nem biztos, hogy a leghatékonyabb módszer strukturális változások előidézésére - legfeljebb, ha abban bízunk, az így kitermelt tudás alapvetően más minőségű, a hagyományos módszerekhez képest eredményesebben eszközölhető ki a segítségével konkrét és mélyreható társadalmi átalakulás. Csakhogy Udvarhelyi a csoporttagok kölcsönös, egymástól való tanulásából származó „intim tudást” tekinti a RAK fő produktumának, a köznek szánt tudás másodlagos a projektjeikben. A „képessé tétel” (empowerment) egyszersmind rövidre is zárja a társadalmi cselekvés lehetőségét: mint amikor Münchhausen báró kénytelen volt a saját hajánál fogva kihúzni magát és lovát a mocsárból.

\section{Tudományos legitimitás}

Úgy tủnik tehát, a RAK - mint módszer, de még inkább mint mozgalom - egyenlősítő hatását a tudományhoz mint erőforráshoz való hozzáférés demokratizálásával gyakorolja, aminek záloga a közérthetőség. Ennek igényét Kovai is megfogalmazta, kifejtve, hogy a tudományos mező önnön legitimitását építve elszakad a társadalom egyéb színtereitől, produktumai a kívülállók számára hovatovább értelmezhetetlenné, értékelhetetlenné válnak. Enyhít ugyanakkor ezen az elzártságon a különféle tudományos, aktivista stb. - logikák, törvényszerüségek betartásával müködő mezők közötti átjárás, a „tudások folyamatos áramlása”.

A RAK esetében a határok átjárhatósága amiatt problémás, mert a tudomány mưvelését (nem pedig pusztán felhasználását) tưzve ki célul, egyszerre nyilvánítja feleslegesnek vagy akár károsnak a tudományos érvényesség elfogadott feltételeit és tart 
számot önmaga tudományként való elfogadására. ${ }^{5}$ Felmerül a kétely: a kapuk tágra nyitása nem válik-e a szakmaiság rovására? És nyomában a kérdés: hogyan gazdagítja a részvételen alapuló kutatás a tudományt?

Udvarhelyi nem a létrehozott tudás minőségében és nem is módszertani újításokban, hanem a kérdésfeltevésben látja a RAK tudományos hozadékát: abban, hogy az érintettek inkább hajlamosak a saját élethelyzetüket illetően releváns problémákból kiindulni. ${ }^{6}$ Ezek feldolgozásához szerencsés azután, ha kapnak forrást, szakmai segítséget, módszereket, illetve lehetőséget az eredmények hasznosítására. Fontos tehát a támogató környezet, a szövetségesek megtalálása, sőt, egyes komoly szaktudást igénylő feladatok akár delegálhatók is (ami természetesen felveti az újabb függőségi viszonyok létrejöttének kockázatát). Udvarhelyi kiemelte a szakmaiság fontosságát, ami például ahhoz is nélkülözhetetlen, hogy a RAK-ot elismertesse a tudományos közegben. Nem veti tehát el, hanem - már a saját önfejlődése szempontjából is - éppenséggel rendkívül értékesnek tartja a tudományt mint olyat, alkalmazottságtól és részvételiségtől függetlenül, és előnyösnek, hogy megvan a szakapparátusa, akiket azért fizetünk, hogy kutassanak. Innen nézve az olyan kijelentései, mint „a tudomány egy nagyon-nagyon szűk elit kiváltsága”, illetve „a RAK alapjaiban megkérdőjelezi a tudomány alapvető hatalmi dinamikáját", kompromisszumos megoldásként egyfajta kooperáció kialakulásának lehetőségét sejtetik, ahol a tudós kutatók szállítják a szakmaiságot és gyakorolják a kontrollt, a bevont érintett kutatók pedig az élményeiket osztják meg és dolgozzák fel, elsajátítva bizonyos, kutatásban és lobbitevékenységben egyaránt hasznosítható készségeket. A fogyaszthatóság végett Udvarhelyiék arra is figyelemmel vannak, hogy a célközönségeknek szövegek helyett adott esetben vizuálisan vagy események formájában adják tovább a tudást. Ha ez így van, a RAK nem biztos, hogy a tudományt fogja forradalmasítani és annak intézményeit demokratizálni, ahogyan azt Udvarhelyi szeretné, de annál több munícióval szolgálhat az aktivizmus, az önreflexió, a civil önszerveződés, sőt esetleg a társadalmi együttmúködés és szolidaritás számára, amit úgyis tevékenysége legfőbb céljának tekint.

\section{Irodalom}

Appadurai, A. (2011): A kutatáshoz való jog. Anblokk, 5: 66-75.

Katona N. (2007): Szégyen és hallgatás. A kutató szerepe a prostitúció elbeszélésében. Szociológiai Szemle, 27(2), 68-87.

Lajos V. (2018): Mi az a részvételi akciókutatás (RAK)? Kik azok a részvételi akciókutatók? Ötféle élmény és értelmezés. Kovász, tél-tavasz, 53-83.

5 Ezzel kapcsolatban ld. Appadurai érvelését arról, hogy mindenkinek képessége és joga van kutatni (Appadurai 2011).

6 Ezzel szemben felvethető, hogy ha ez a tudományos diskurzus, szemléletmód és előzmények ismeretének hiányát, már tesztelt összefüggések figyelmen kívül hagyását is jelenti egyben, akkor a saját élményre szorítkozó irányválasztás nem feltétlenül szerencsés. A témaválasztás adekváttá, rugalmassá tétele egyébként más módszertanokban is lényeges elem, gondoljunk csak az elöregyártott kutatási tervet nélkülöző, korábbi eredményekre épülő ún. „megalapozott elméletet” (grounded theory) alkalmazó kutatásokra. 